\title{
IbM PELATIHAN BUSINESS PLAN PADA UMKM DI KOTA TEGAL
}

\author{
Farida Ida $^{1}$, Aryanto $^{2}$, Sunandar $^{3}$, Hetika $^{4}$, Krisdiyawati $^{5}$ \\ 1.2.3.4.5 Program Studi Akuntansi \\ Politeknik Harapan Bersama \\ Jl. Mataram No. 9 Tegal
}

Kode Pos 52142 Telp (0283) 352000, Fax (0283) 353353

Email: idafaridah90@yahoo.com , ary.arya70@gmail.com , nandars2ak@gmail.com , hetika_tika@yahoo.co.id, kris.diyawati@gmail.com

\begin{abstract}
Abstrak
Perencanaan bisnis merupakan alat yang sangat penting bagi pengusaha maupun pengambil keputusan kebijakan perusahaan. Tujuan perencanaan bisnis adalah agar kegiatan bisnis yang akan dilaksanakan maupun yang sedang berjalan tetap berada di jalur yang benar sesuai dengan yang direncanakan. Perencanaan bisnis juga merupakan pedoman untuk mempertajam rencana-rencana yang diharapkan, karena dalam perencanaan bisnis kita dapat mengetahui posisi perusahaan kita saat ini, arah tujuan perusahaan dan cara mencapai sasaran yang diinginkan. Usaha Mikro Kecil dan Menengah (UMKM) di kabupaten Tegal selama ini belum dapat menerapkan perencanaan bisnis dalam melaksanakan kegiatan usahanya. Jika dilihat dari segi potensi, UMKM di Kabupaten Tegal sangat memiliki banyak peluang untuk mengembangkan usahanya. Oleh karena itu pada kegiatan Pengabdian Kepada Masyarakat ini, kami tim dosen Prodi Akuntansi akan memberikan pelatihan kepada UMKM terkait dengan perencanaan bisnis yang bertujuan untuk mengembangkan usahanya. Permasalahan utama yang berkaitan dengan pelaksanaan pengabdian masyarakat ini adalah UMKM yang berkembang di Kabupaten Tegal saat ini masih belum menerapkan ilmu perencanaan bisnis dimana perencanaan bisnis sangat diperlukan sebagai alat yang sangat penting bagi pengusaha maupun pengambil keputusan kebijakan perusahaan agar kegiatan bisnis yang akan dilaksanakan maupun yang sedang berjalan tetap berada di jalur yang benar sesuai dengan yang direncanakan selain itu juga dapat digunakan sebagai alat untuk mencari dana dari pihak ketiga, seperti pihak perbankan, investor, lembaga keuangan dan sebagainya.
\end{abstract}

Kata kunci : Bussines Plan, Usaha Mikro Kecil dan Menengah 


\section{PENDAHULUAN}

Perencanaan bisnis merupakan alat yang sangat penting bagi pengusaha maupun pengambil keputusan kebijakan perusahaan. Tujuan perencanaan bisnis adalah agar kegiatan bisnis yang akan dilaksanakan maupun yang sedang berjalan tetap berada di jalur yang benar sesuai dengan yang direncanakan. Perencanaan bisnis juga merupakan pedoman untuk mempertajam rencanarencana yang diharapkan, karena dalam perencanaan bisnis kita dapat mengetahui posisi perusahaan kita saat ini, arah tujuan perusahaan dan cara mencapai sasaran yang diinginkan. Perencanaan bisnis juga dapat dipakai sebagai alat untuk mencari dana dari pihak ketiga, seperti pihak perbankan, investor, lembaga keuangan dan sebagainya. Bantuan dana yang diperlukan tersebut dapat berupa bantuan dana jangka pendek untuk modal kerja maupun jangka panjang untuk peruasahaan atau biaya investasi. Setiap rencana bisnis memiliki karakteristik yang berbeda. Perencana bisnis harus dapat menangkap faktor-faktor apa saja yang dimiiki oleh perusahaan tersebut sehingga penggunaannya dapat dioptimalkan. Selain itu perencna bisnis dapat membuat kerangka pengendalian faktor-faktor keberhasilan, sehingga konerja actual perusahaan dapat dievaluasi secara terus menerus untuk menuju kearah yang lebih baik. Usaha Mikro Kecil dan Menengah (UMKM) di Kota Tegal selama ini belum dapat menerapkan perencanaan bisnis dalam melaksanakan kegiatan usaha nya. Jika dilihat dari segi potensi, UMKM di Kota Tegal sangat memiliki banyak peluang untuk mengembangkan usahanya. Oleh karena itu pada kegiatan Pengabdian Kepada Masyarakat ini, kami tim dosen Prodi Akuntansi akan memberikan pelatihan kepada UMKM terkait dengan perencanaan bisnis yang bertujuan untuk mengembangkan usahanya.

\section{METODE}

Metode pelaksanaan kegiatan dalam program pengabdian masyarakat ini akan dilakukan dengan beberapa cara diantaranya adalah :

\subsection{Pemetaan (mapping)}

Pemetaan dilakukan pada saat menganalisis situasi denga memetakan permasalahan apa yang dihadapi dan solusi apa yang dibutuhkan. Dari hasil pemetaan yang dibutuhkan oleh UMKM adalah penjelasan tentang perencanaan bisnis sebelum memulai usaha.

\subsection{Wawancara dengan UMKM Kelurahan Debong Lor Kota Tegal}

Wawancara juga dilakukan kepada beberapa UMKM tentang program pelatihan apa saja yang telah diikuti dan dipahami oleh para UMKM agar memiliki gambaran materi perencanaan 
bisnis apa saja yang dibutuhkan oleh para umkm untuk menambah pengetahuan dan skill tentang pelatihan perencanaan bisnis.

\subsection{Perumusan masalah dan Solusi}

Perumusan masalah dilakukan dengan tujuan mencari solusi yang dapat dilakukan.

\subsection{Metode penyelesaian masalah}

Metode penyelesaian masalah dalam kegiatan pengabdian masyarakat ini adalah dengan melakukan pelatihan untuk menambah wawasan bagi UMKM tentang perencanaan bisnis, serta menumbuhkan kesadaran pada UMKM tentang pentingnya sebuah perencanaan sebelum memulai usahanya..

\subsection{Tahap implementasi dan pelaksanaan}

Pelaksanaan Pengabdian Kepada Masyarakat ini dilakukan dengan menggunakan metode ceramah, tutorial dan diskusi. Adapun sistematika pelaksanaan kegiatan pengabdian adalah sebagai berikut:

\section{Metode Ceramah}

Peserta diberikan motivasi agar memiliki pemahaman tetang macam-macam kegiatan usaha. Peserta juga diberikan gambaran tentang perkembangan bisnis di Indonesia khususnya program perencanaan sebelum memulai usaha.

\section{Metode Tutorial}

Peserta pelatihan diberikan materi perencanaan bisnis. Peserta pelatihan dipandu untuk menyimak bagaimana cara merencanakan sebelum memulai usahanya dan terkait dengan membuat catatan harian.

\section{Metode Diskusi}

Peserta pelatihan diberikan kesempatan untuk mendiskusikan permasalahan yang berkaitan dengan perencanaan sebelum memulai usahanya.

\section{HASIL DAN PEMBAHASAN}

Kegiatan pengabdian masyarakat ini dilakukan disatu tempat yaitu di Kelurahan Debong Lor Kota Tegal. Kegiatan pengabdian masyarakat ini di hadiri oleh 17 orang yang ada di Kelurahan Debong Lor Kota Tegal. Kegiatan ini disambut positif oleh seluruh warga karena mereka membutuhkan pelatihan perencanaan bisnis dilihat dari segi analisis pasar dan pemasaran, analisis produksi dan SDM, analisis keuangan dan analisis pengembangan usaha dan resiko serta motivasi semangat berbisnis tentang perkembangan dunia usaha di Indonesia. Banyak pertanyaan yang di lontarkan serta harapan untuk adanya forum untuk sharing dan konsultasi tentang perkembangan usaha yaitu tentang perencanaan bisnis bagi UMKM dan dosen. 


\section{Materi 1 Tentang Motivasi Semangat Berbisnis}

Berisi tentang bagaimana memberikan motivasi semangat berbisnis bagi UMKM menghadapi perkembangan persaingan yang semakin ketat dalam dunia usaha yang menuntut para UMKM untuk dapat meakukan inovasi dalam menunjang kegiatan usaha nya saat mereka menghadapi persaingan.

\section{Materi 2 Tentang Analisis Pasar dan Pemasaran}

Berisi tentang strategi Kita melakukan pemasaran produk. Dalam tindak lanjutan biasanya orang menggunakan rencana pemasaran (marketing plan) untuk menjelaskan detill atau strategi pemasaran.

\section{Materi 3 Tentang Analisis Produksi dan SDM}

Analisis produksi menjelaskan sistem operasi bisnis Kita. Misal bisnis Kita adalah jenis produksi atau manufaktur, perlu diketahui bagaimana proses dari penerimaan pesanan, produksi, distribusi barang-barang dan penagihan. Jika bisnis Kita adalah bisnis jasa, Kita harus menuliskan dengan jelas bagaimana cara Kita menyalurkan jasa kepada pembeli dan menceritakan orang-orang yang dibutuhkan dari kompetensi, jumlah orang yang dibutuhkan. Rencana pengembangan sumber daya manusia. Bagi sebagian calon entrepreneur bagian ini biasanya dianggap remeh, tetapi hal inilah yang salah satunya penentu kecepatan dalam bisnis.

\section{Materi 4 Tentang Analisis Keuangan}

Di sesi ini menjelaskan proyeksi (forecasting atau peramalan) pendapatan dan pengeluaran, pengembalian modal (break event point), pengembalian atas investasi (return on investment), perhitungan penggunaan daya ungkit (leverage) dan lainnya.

\section{Materi 5 Tentang Analisis perkembangan usaha dan resikonya}

Rencana pengembanagn usaha adalah salah satu bagian yang dilihat penting bagi sorang investor.

Calon investor akan melihat seberapa besar usaha yang akan Kita buat. Termasuk didalamnya adalah rencana keluar atau exit strategy dari bisnis Kita. Risiko usaha adalah hal-hal yang terkait risiko atas bisnis Kita, misal risiko operasional, risiko bisnis, risiko likuiditas atau risiko keuangan dan lainnya. Risiko usaha tidak hanya berhenti pada identifikasi risiko, tetapi juga strategi Kita menghadapi atau mengurangi dampak dari risiko tersebut. 


\section{KESIMPULAN}

Kegiatan pengabdian masyarakat yang telah dilakukan oleh Prodi Akuntansi bekerjasama dengan Kelurahan Debong Lor Kota Tegal dapat dikatakan berhasil, karena tingkat kehadiran yang lebih dari $70 \%$ dari total undangan yang telah disebarkan (daftar hadir terlampir).

\section{SARAN}

1. Kegiatan pengabdian masyarakat yang bekerjasama dengan Kelurahan Debong Lor Kota Tegal semacam ini perlu di tingkatkan lagi. Agar fungsi akademisi bisa tersalurkan untuk lembaga dan waraga yang membutuhkan pelatihan dan program terbaru sesuai dengan kebutuhan di lapangan.

2. Perlunya ada lembar evaluasi yang diedarkan kepada para peserta pelatihan untuk mengetahui tingkat kebutuhan dan feed back peserta tentang pelatihan ini.

\section{UCAPAN TERIMA KASIH}

Penulis mengucapkan terima kasih kepada Politeknik Harapan Bersama Tegal yang telah memberi dukungan finansial terhadap kegiatan Pengabdian Kepada Masyarakat oleh P3M Politeknik Harapan Bersama Tegal.

\section{DAFTAR PUSTAKA}

[1] Danuar, Dani (2013). Pengembangan Usaha Miro Kecil dan Menengah (UMKM) berbasis ekonomi kreatif di kota Semarang. Fakultas Ekonomika dan Bisnis, Universitas Diponegoro.

[2] Megginson,L.C. Byrd,MJ \& Megginson, W.L (2003) Small Business Management: An entrepeneur's quidebook, (4thed).New York: Mc.Grow-Hill

[3] Naluriyanti, Fitri (2012). Business Plan: rencana pendirian pusat kebugaran dan kecantikan khusus wanita 'La Femme” tinjauan khusus pemasaran. Jakarta: Megister Manajemen, Fakultaas Ekonomi, Universitas Indonesia.

[4] Kusumawati, Ida (2012). Business Plann: rencana pendirian pusat kebugaran dan kecantikan khusus wanita "La Femme” Tinjauan Khusus dan Analisis Keuangan. Jakarta: Fakultas Ekonomi, Universitas Indonesia 